\title{
The Positions of Russia and Croatia Shipbuilding Products on World Markets and Prospects of Co- Operation (Analytical Overview)
}

\section{Položaj ruskih i hrvatskih brodograđevnih proizvoda na svjetskim tržištima i mogućnosti suradnje (analitički pregled)}

\author{
Irina R. Tulyakova \\ Saint Petersburg State University \\ Faculty of Economics \\ Department of Economics and Economic Policy \\ Saint Petersburg, Russia \\ e-mail: i.tulyakova@spbu.ru
}

\author{
Victor V. Dengov \\ Saint Petersburg State University \\ Faculty of Economics \\ Department of Economics and Economic Policy \\ Saint Petersburg, Russia \\ e-mail: v.dengov@spbu.ru
}

\author{
Elena Gregova \\ University of Žilina \\ Faculty of Operation and Economics of \\ Transport and Communications \\ Žilina, Slovakia \\ e-mail: elena.gregova@fpedas.uniza.sk
}

\author{
DOI 10.17818/NM/2019/3.9 \\ UDK 629.5:623.8(497.5)(470) \\ Professional paper / Stručni rad \\ Rukopis primljen / Paper accepted: 7. 1. 2019.
}

\section{Summary}

Both Russia and Croatia are the great seafaring nations with glorious past, complicated present and, hopefully, a rewarding future. The countries that historically had long sea borders are almost destined to become the global shipbuilding centres. Since the ancient times, the marine shipping routes have connected the most distant nations, countries and entire continents through trade and economic relations. At the same time, the high seas were also a place for the constant battles between the fleets of the major seafaring nations. Thus, both civil and naval shipbuilding was and will always be of utmost importance for any country with a sea access. The product of this industry stays in demand at any time and under any circumstances - both during the periods of growth and the times of crises. The shipbuilding is subject to the same kind of difficulties as the economy as a whole, but due to the technological specifics of this industry it has some additional specific problems. This article deals with the comparative analysis of the recent and current state of the shipbuilding industries of Croatia and Russia. We tried to find out the problems that are similar for the shipbuilding industries of both countries, as well as their national particularities. The main difficulty for the comparative analysis was the fact that while the major part of the Croatian shipbuilding is civil, the Russian industry is predominantly naval. However, it does not preclude the existence of common problems, for the research of which the comparative analysis could be a useful tool.

\section{Sažetak}

I Rusija i Hrvatska poznate su pomorske zemlje sa slavnom pomorskom tradicijom, složenim okolnostima u današnjim vremenima i, nadajmo se, budućnošću koja obećava. Zemlje koje imaju dugu obalu gotovo neizbježno postaju svjetska središta brodogradnje. Od davnih su vremena putovi prijevoza morem povezivali najudaljenije narode, zemlje i cijele kontinente s pomoću trgovine $i$ ekonomskih odnosa. Istovremeno, oceani su predstavljali mjesta stalnih sukoba između flota najvećih pomorskih nacija. Stoga je i civilna i ratna brodogradnja bila i bit će uvijek najznačajnija za svaku zemlju koja ima izlaz na more. Uvijek postoji potražnja za proizvodima ove industrije - i u vrijeme rasta i u vrijeme krize. Brodogradnja je izložena jednakim problemima kao i ekonomija u cjelini, ali zbog svojih tehnoloških posebnosti ova industrija ima dodatne specifične probleme. $U$ ovome radu daje se komparativna analiza stanja brodograđevnih industrija $u$ Hrvatskoj i Rusiji kakve su bile u posljednje vrijeme i kakve su danas. Pokušalo se otkriti probleme u brodograđevnoj industriji koji su slični u objema zemljama, kao i različitosti. Najveća prepreka u komparativnoj analizi bila je činjenica da je većina brodogradnje u Hrvatskoj za civilne potrebe, dokje u Rusiji pretežito za vojne potrebe. Međutim, time se ne isključuju zajednički problemi, a ova komparativna analiza može poslužiti boljem istraživanju tih problema.

\section{KEY WORDS}

civil shipbuilding military shipbuilding branch problems state support

\section{INTRODUCTION / Uvod}

Both Russia and Croatia are the countries for which the shipbuilding traditionally constituted one of the most important industries of their national economies. The specific geographical position of Croatia in the Adriatic Sea and the Mediterranean as a whole, and the length of its sea borders have naturally contributed to the development of the shipbuilding in this country since the ancient times. However, the time when this industry and especially its naval segment positively flourished on the Adriatic coast of current Croatia was the so-called "age of sail". On the staples of the shipyards that sprouted everywhere 
largely due to the Austrian Empire, the steam-power destroyers, cruisers and battleships gradually replaced the sailing boats. The advantageous geopolitical position of the shipyards and the local climate favourable for the shipbuilding attracted the customers from the countries that at the beginning of the 20th century aspired for the naval dominance in the Mediterranean and all over the Atlantic Ocean [1].

Before Peter I, Russia was practically land-locked from the Black and Baltic seas. Its only sea access was through the seas of the Arctic Ocean, which lacked any significant economic and strategic importance. In fact, Russia has acquired its first naval vessel only in the late 17th century during the reign of Czar Alexei Mikhailovich. However, in 18th century, in the course of the long battles with Turkey over the access to the Black Sea and Sweden over the access to the Baltics, Russia has become one of the major seafaring nations, bound by the waters of many seas with the tremendous length of the sea borders. Besides, Russia was and still is the largest country in the world and has many rivers and the river and sea transport plays an important role in connecting its internal regions both with each other and to the centre of the country. Due to the specific geographical position of Russia, huge transit streams go through our country (mainly through the Northern Sea Route [2]) from Europe to Asia and back. Moreover, there is the fishing fleet and the scientific arctic research. All of the above creates a demand for the products of the civil shipbuilding. On the other hand, there is the economic axiom of the deficit of and the constantly growing demand for the resources of our planet, which implies the necessity to guard our own resources and explains, why Russia has traditionally promoted and developed the production of various weapons and military technique, and among them - as one of the most important elements - the naval shipbuilding.

The Russian and Croatian shipbuilders have a long and fairly well established co-operative relationship. In 1990s, when Croatia became a target of aggression, the Russian shipbuilders signed contracts with the Croatian shipyards for the building of ships for the Russian fleet; and in our opinion, the Russian contracts of that period helped the Croatian shipbuilding industry to "stay afloat" and weather the most difficult times. We have not nearly realized all the possibilities for co-operation and reciprocal trading between Croatia and Russia; however, even the existing level provides a stable basis for the profitable partnership of our countries. The changing conditions of the global market urge us to look for the new models of co-operation. For example, the coordinated co-operation of the Russian and Croatian banks helps to realize the ambitious plans of the Croatian shipbuilding on the Caspian Sea and the Russian Far East [3]. Despite the sanctions, trade between Croatia and Russia is growing steadily. At the same time, some projects have all the strategic features, for example, the participation of the Brodotrogir shipyard in the construction of a new icebreaker fleet in Russia. Even the accession of Croatia to NATO membership does not present an insurmountable handicap for the co-operation in the field of naval shipbuilding. It is well known, that, for instance, the USA is still buying Russian rocket engines, despite all the visible signs of dire competition in the military field. Politics is politics and business is business.

\section{METHODOLOGY / Metodologija}

The analysis of the problems concerning the current state of the shipbuilding industry includes, primarily, the study of the regulations, and the Executive Orders of the President of the Russian Federation (RF) and the Government. The assessment encompasses the process of their implementation and the results thereof, the structural changes and the spatial location of the subjects of management. Of great importance for accurate assessment of prospects for the development of industry is a study of business environment [4].

The statistical base for assessing the state of affairs in the world civil and military shipbuilding, as well as the competitiveness of the Croatian and Russian segments in international markets, was provided by information provided by various national and supranational analytical centres, such as Sudostroenie.info, Stockholm International Peace Research institute (SIPRI), Centre for Analysis of World Arms Trade (CAWAT), Centre for Analysis of Strategies and Technologies (CAST), OAOOSK.ru and others.

However, using the data of these research centres one should take into the account that the different calculation methods provide the widely differing results. We have touched upon this problem more thoroughly in our previous article [2]. For the study of the domestic and global markets of the civilian shipbuilding, the authors used the statistical data provided in the annual reports of the United Shipbuilding Corporation (USC).

The data evaluation tools implemented in this article are the statistical and system analysis methods.

\section{THE CURRENT STATE OF THE SHIPBUILDING INDUSTRY IN RUSSIA AND CROATIA AND THEIR PLACE IN WORLD MARKETS / Sadašnje stanje brodograđevne industrije u Rusiji i Hrvatskoj te njihovo mjesto na svjetskim tržištima}

Right now, the global shipbuilding, especially the civil one, undergoes a very difficult period. The reason for it lies in the very active shipbuilding during the period preceding the global financial crisis of 2008-2009 [5][6]. The long-term character of the building and delivery process in this industry, its inertia, and the economic contraction caused by the crisis created the surplus of tonnage [7].

To save and preserve the national shipyards many states (such as South Korea, Japan, and China) provided them with a sufficient governmental financial support. The different crisis developments and recovery scenarios implemented by the different countries strengthened the tendency for the relocation of the centre of the global shipbuilding to the Far East. During the period of financial crisis, the spread between the shares of the Eastern and European shipbuilders increased due to the low labour and production costs in the Asian shipyards [8].

The beginning of the shift towards the Eastern shipbuilders became noticeable since the late $20^{\text {th }}$ century. During the first half of the 20th century, the main role in the global shipbuilding belonged to the countries of the Western Europe. However, already in the early 1970s, Japan has won the first place in the total volume of the shipbuilding. By the end of the 1970s, South Korea has also become one of the major players in this industry; and when China entered this market in 1990s, the relocation of the centre of the global shipbuilding to the East became inevitable.

As noted in the analytical article on sudostroenie.info, the key factors for the development of the global shipbuilding market are - the new-building portfolio, the volume of ships built in a 
particular year and the newly acquired orders. According to the statistics, there were 1832 ships with the total tonnage of 39.2 million registered tons built in 2017 . This number is $41 \%$ lower than the one for the previous year.

Some growth is notable in relation to the new orders. With 1388 ships with the tonnage of 59.6 million reg. tons, it is more than three times higher than in 2016. The total volume of the global new-building program now includes 4598 ships with the tonnage of 143.7 million reg. tons [9].

The leader of the global shipbuilding in regards of the newbuilding programme is without a doubt China (39\%), followed by South Korea (25\%) and Japan (21\%) (see figure 1 ).

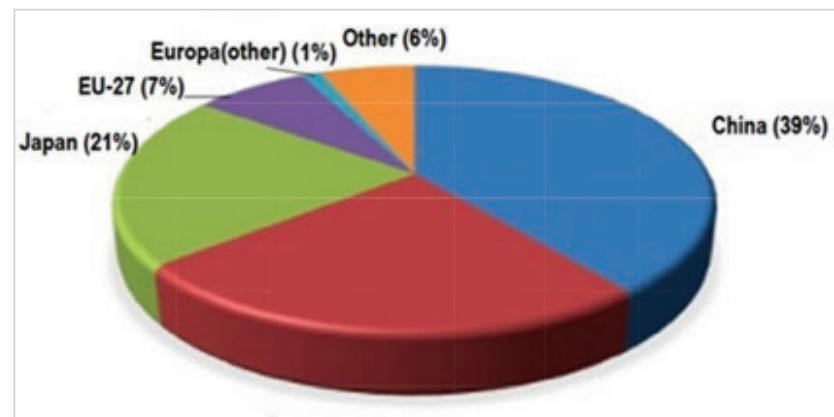

South Korea (25\%)

Figure 1 Structure of the shipbuilding orders portfolio by countries, 2017

Slika 1. Prikaz narudžbi brodova po zemljama, 2017.

Source: http://sudostroenie.info/analitika/91.html

In the 4th quarter of 2017, China has acquired 167 new shipbuilding orders with the total tonnage of 7.8 million reg. tons, which constitutes $53 \%$ of the global volume. South Korea received 46 new orders with the tonnage of 5.4 million reg. tons, while Japan acquired the orders for the same number of new ships, but with the tonnage of only 0.4 million reg. tons, which means that in Japan the customers tend to order the ships of lower tonnage.

The main part of the new-building program consists of the tankers, bulkers and cruise ships, and the latter are noticeable only due to their tonnage. In the whole program, there are only 96 cruise ships, compared to 607 bulkers and 314 crude oil carriers. The global shipbuilding expects that 3250 ships with the total tonnage of 70.9 million reg. tons will be finished in 2018 [9].

Presently (in the years 2015-2016) the share of the European shipyards in the total volume of all the shipbuilding contracts in the world is only $13 \%$ [10]. Yet, though in the last half of century the share of the European shipbuilders in the global market has considerably diminished, during the recent crisis they suffered less damage than the shipyards of South Korea or China, which were affected by the lowering of the demand and terminations of contracts, especially for the offshore ships. In the last eight years (from 2009), almost two thirds of the global shipyards were closed for lack of orders. Altogether, in the world there currently exist about 350 shipyards, 30\% of which are now working on their last projects and face the closure thereafter. This is the data provided on November 26, 2017 by the Hamburg Shipbuilding and Ocean Industries Association (VSM)[11]. The reason for the global crisis was the lack of current orders caused by the excessive production of the last few decades. The prices for the aging vessels fell to the lowest level ever. The global economy now needs only the large lift-on/lift-off ships, which can ensure the cheap transportation of cargo, and the cruise liners. As a result, the workflow of the European shipyards is more stable, largely due exactly to their specialization in building of the passenger and specialized ships.

The most flourishing period for the Croatian shipbuilding fell on the 1980s. At that time, Croatia was at the fifth, and according to some experts even third (!) place among the major global shipbuilders. The Croatian shipbuilding industry delivered its production - mostly civil ships of 150-170 thousand tons of deadweight - to the dozens of countries throughout the world [1]. Already in 1990s though, Croatia has lost its position and ceded the leadership to the countries of the European Community and the Asia-Pacific Region.

In this kind of situation, the orders for a whole series of ships made by the Russian Novorossiysk, Northern and Primorsk Shipping Companies were very helpful for the preservation of the Croatian shipbuilding industry. The co-called"limited"reform of the shipbuilding industry, carried out in mid-1990s was only partially successful [1]. The major and medium shipyards of the country («Hrvatska Brodogradnja Jadranbrod d.d.»), officially transferred to the private sector, but practically - receiving the continuous state support, were suffering considerable loss caused by the remaining surplus production capacities, surplus personnel, lack of modern technologies, low productivity and ineffective management. The only shipyard that showed profit was the private shipyard "Victor Lenac", the main shareholders of which were Dutch and Italian companies, and the chief investor - the German Thyssen Krupp industrial group. This shipyard specialized in the shipbuilding and overhaul of ships and offshore oil and gas rigs according to the foreign individual orders.

The desire to conform to the requirements of the EC made the Croatian government to put five unprofitable shipyards up for the international auction, sell the surplus capacities, and carry out the restructuring and diversification of the shipyards within the industry. In fact, loss-making and even bankruptcy of enterprises cannot be viewed only in a negative way. This is an inevitable and even necessary stage of the current socioeconomic evolution, which can be a stimulus for innovation, investment and global welfare [12][13][14][15][16].

Though the reform of the Croatian shipbuilding is not yet complete, its success is already obvious. At the beginning of 2016, the estimated cost of the current shipbuilding contracts was 1.65 billion dollars. According to the statement of the Croatian government from January 12, 2016, the Croatian shipbuilding industry is now (at the year-end of 2015) on the second place in Europe and tenth - in the entire world. Only the major shipyards in Split, Trogir, Rijeka and Pula signed the contracts worth 1.75 billion dollars for the building of 44 ships with the total deadweight of 675 thousand tons. Besides them, the industry also has other contracts, bringing in considerable additional profit [10]; and with all that - the Croatian shipyards still have not fully filled the quota, stipulated for them by the EC, and are presently working only on $25 \%$ of their capacity. At the same time, we cannot say that all the problems have been solved. For example, the shipbuilding refers to those industries that are most currency exposure. It receives payments in dollars, 
but covers expenses in Kuna. The fall of the dollar necessarily leads to losses [17].

The prospects of Russia not only in the foreign, but also on the domestic market of the demand for the civil shipbuilding production are considerably bleaker. In the global market the Russian vessels take up a minuscule share (less than $1 \%$ of the total volume of sales), though there is a specific traditionally Russian niche: the building of the icebreakers, research vessels, arctic offshore ships etc.

The demand of the Russian domestic market is broad. Without any considerable investments during the last 20 years, the transportation fleet of Russia has dilapidated and will need a great number of various river and sea vessels for a complete renewal. At the same time, the participation of the domestic production in filling the demands of the water transportation has been continuously diminishing. By now, only $5 \%$ of the total volume of transportation of the domestically produced foreign trade or transit cargo happens under the Russian flag - thirty years ago this share was up to 70\% [18]. A situation like this means a considerable danger of monopolization of the transportation routes by the foreign shipping companies, which may later dictate their own shipping prices. The fishing fleet, which has a great importance for the ensuring of the food supply security, is also in need of a serious renewal.

One of the reasons for such a discrepancy between the domestic demand and the offer of the domestic shipbuilding production is a historical situation, where during the second part of the 20th century the civil shipbuilding within the Russian territory was developing in a clearly insufficient manner. The major part of the domestic demand was satisfied by the production of the countries of former socialist camp (Poland, East Germany), as well as by some capitalist suppliers (Finland). For a long time, the naval shipbuilding has remained the main segment of the Russian shipbuilding industry, due, of course, to the arms race, the "cold war", and the necessity to maintain the military parity with the USA.

Despite the hopeful predictions of the analysts about the leading positions of the Russian producers in the field of Naval equipment and armament (NEA), it is quite obvious by now that there are some problems in the Russian shipbuilding industry that may inhibit further development of both civil and naval shipbuilding, and - considering the importance of the industry for the whole country - endanger the national, transportation, fuel and energy and food supply security.

One of the problems lies in the disproportional structure of the industry with the heavy incline to the better-developed naval shipbuilding. In the face of a considerable demand for the civil ships, the domestic market mostly consists of the imported vessels (and more often than not, these vessels are far from new). Our naval shipbuilding, on the other hand, for a long time has been filling the demand of the naval forces of foreign countries. Since all the Russian shipyards produce both the civil and naval production, it is clear that for the full use of their capacity they should have the orders for both.

The other factors inhibiting the development of the national shipbuilding are the imperfect legislation and the lack of either a strong state support for the civil shipbuilding or a proper shipbuilding financing system. The long-term character of the shipbuilding throughout the world leads to the necessity of taking loans. Such credits should be big (up to $80 \%$ of the building cost), long (up to 10 years) and with the lowest possible interest (in order to cheapen the production). This is the reason, why many countries (for example, Italy, and primarily - Genoa; Finland and Malta) have specific state programs for the support of this cluster, which allows them to heighten the global competitiveness, and to support and actively develop the shipbuilding cluster even in times of crisis, reduce financial risks [19][20]. As we know, Russia suffers from the lack of "cheap and long money", which means that here you can only take a credit for shorter term and for bigger interest than abroad, which, in its turn, makes the national shipbuilding more expensive in comparison to its foreign competitors. In addition, the Russian producers often need to purchase imported ship equipment, subject to customs duties, that does not help reduce costs. We need to point out here, that the low level of the state involvement in the field of civil shipbuilding not only reduces the marketability of the Russian vessels, but also creates some additional threat for the economic security of the country.

The insurance problem in the shipbuilding industry is also one of the dire ones. The problem is caused by the specifics of the industry: the long production cycle; specific production assets, meaning tremendous costs that may be lost in the case of a failure to fulfil the multi-billion order; possible penalties; long pay-off periods; higher risks related to the operation of the marine facilities etc. All of that makes the insurance process of the shipbuilding risks more complicated and expensive, leads to the problems of moral hazard and adverse selection, and demands the development of specific risk identification procedures and the procedures preventing the opportunistic behaviour of the parties [21].

The big problem of the shipbuilding, common to the many other industries within the Russian economy, is the wear of fixed assets, the decline in workforce capacity, the technological gap between the Russian shipbuilders and their foreign competitors, the need for the integration of new kinds of equipment (for example, the heavy-lift cranes for the prefabricated large-block shipbuilding). Thus, in its current state, the Russian civil shipbuilding barely strives to survive, rather than to develop, robbed of the opportunity to use their key success factors. All of it due to the almost complete lack of any state financing of this industry since the 1990s.

Unless we find a successful solution for these problems, they may present a serious threat to the future of Russia. It may be a threat of the eventual complete crowding out of the national civil shipbuilders not only from the foreign market (our presence there is barely noticeable as it is), but also from the domestic and very broad one (which will be a threat mainly for our transportation independence). Yet, if we lose a competitive civil shipbuilding, we will also eventually face difficulties in the production of the naval technique (which will be already a threat to the national security). Besides, since the shipbuilding industry employs and otherwise involves a great number of workers, if the development of the industry follows the unfavourable scenario, it may also lead to serious social problems. 


\section{MILITARY SHIPBUILDING OF RUSSIA AND CROATIA AT THE PRESENT STAGE AND THEIR POSITION IN THE WORLD MARKETS OF NAVAL EQUIPMENT AND ARMAMENT / Trenutno stanje vojne brodogradnje u Rusiji i hrvatskoj te njihov položaj na svjetskim tržištima vojne opreme $i$ naoružanja}

For many decades, in the global arms markets, including NEA one, the main competitors were the USA and the USSR/Russia. According to the data of SIPRI, during the period of the "cold war" from 1950 to 1991, the USSR has exported the products of naval shipbuilding in the amount of 32447 million dollars out of the total amount of export - 455265 million dollars (7\%). The USA during the same period has exported the naval technique in the amount of 31817 million dollars out of 424932 million dollars accordingly (7,5\%). During the period from 1992 to 2016, Russia exported NEA in the amount of 14832 million dollars out of the total volume of export - 126862 million dollars $(11,7 \%)$. The naval export of the USA during the same period (20152016) constituted 12463 million dollars out of the total amount of export - 234460 million dollars (5\%) [22].

The global market of the of the armaments and military equipment ( $\mathrm{AME}$ ) has been lately enjoying a continuous growth, and its share in the global military expenditures and the global GDP has been steadily growing as well (see table 1). Only during the last decade, the volume of the global AME market has increased by 1.5 times in comparison to the global GDP. The unending strife in some parts of the world, such as Northern Africa, Near, Middle and Far East, definitely contribute to this growth.

The relation of the military export of a country to its military expenditures and the volume of the national GDP clearly demonstrates the importance of the arms trade for this country and, indirectly, its level of militarization (see table 2).

The end of the arms race, which for Russia corresponded with the difficult period of transition to the market economy, led to the reduction of the state financing for the entire field of military research and production, including the naval shipbuilding. For several decades, the state has not been sufficiently financing the scientific research either in civil, or in naval shipbuilding. For many well-known shipyards, the only way to survive and further the military science was to do so by fulfilling the export orders. The weapons and military technique of soviet production had acquired a reasonably high reputation in the global market during the years of "cold war". This wellearned reputation later spread onto the whole production of the Russian military-industrial complex, including AME.

The majority of the Russian developers and producers of civil and naval vessels are united into the United Shipbuilding Corporation. The USC open joint stock company has been established in 2007 and is the biggest shipbuilding company in Russia. The main field of the USC's activities is the fulfilment of the state defence order in regards of the development, building, overhaul and maintenance of the naval ships and vessels of the Russian Naval Forces.

We can estimate the importance of the USC as the military company based on its positions in the ratings of various agencies. For example, in the SIPRI version of the rating of 100 biggest military companies of the world the USC for the last few years stayed approx. on the 15th-19th places. The ratio of the naval sales to the total sales of the company is $80-90 \%$. It shows that the shipbuilding industry in Russia, as previously in the USSR, is primarily concentrating on the naval shipbuilding. Though all the Russian shipbuilding facilities produce the civil products alongside the naval ones, the share of civil products is still relatively small [22]. The production and commercial results

Table 1 The volume of the global export / import of arms and military equipment (bln. US\$ at current prices) and their share in the global GDP and military expenditures (\%)

Tablica 1. Ukupan svjetski izvoz/uvoz oružja i vojne opreme (mlrd. USD po sadašnjim cijenama) i njihov udio u svjetskom BDP-u i vojnim troškovima (\%)

\begin{tabular}{|c|c|c|c|c|c|c|c|c|c|}
\hline & 2010 & 2011 & 2012 & 2013 & 2014 & 2015 & 2016 & 2017 & 2010-2017 \\
\hline Volumes of world export / import AME & 53,3 & 58,7 & 56,9 & 55,5 & 68,1 & 71,7 & 86,0 & 89,7 & 539,8 \\
\hline $\begin{array}{l}\text { Share of exports of arms and military equipment } \\
\text { from the world's military expenditure (\%) }\end{array}$ & 3,46 & 3,59 & 3,50 & 3,41 & 4,17 & 4,57 & 5,40 & 5,49 & 4,20 \\
\hline AME export/ import to world GDP (\%) & 0,081 & 0,081 & 0,076 & 0,073 & 0,087 & 0,097 & 0,115 & 0,113 & 0,090 \\
\hline
\end{tabular}

Source: Yearbook of CAWAT 2018 [23] (http://www.armstrade.org/files/yearly_2018_3_1.pdf)

Table 2 The relation of the volume of AME export of the country to its GDP and military expenditures for the major arms exporting countries (for the period from 2009 to 2016)

Tablica 2. Povezanost ukupnog AME izvoza zemlje s njezinim BDP-om i vojnim troškovima u glavnim zemljama izvoznicama oružja (za razdoblje 2009. - 2016.)

\begin{tabular}{|r|l|c|c|c|c|c|}
\hline № & country & $\begin{array}{c}\text { Exports for the } \\
\text { period, mln. US\$ }\end{array}$ & $\begin{array}{c}\text { Military spending in the } \\
\text { period, mln. US\$ }\end{array}$ & $\begin{array}{c}\text { GDP, bln. } \\
\text { US\$ }\end{array}$ & $\begin{array}{c}\text { AME export/ Military } \\
\text { spending } \%\end{array}$ \\
\hline 1 & Israel & 18552,9 & 123634,0 & 2181,7 & 15,006 \\
\hline 2 & Russia & 79988,6 & 386879,0 & 14073,6 & 20,675 \\
\hline 3 & Ukraine & 3977,0 & 17140,0 & 1092,6 & 23,203 & 0,850 \\
\hline 4 & Belarus & 1666,6 & 6253,0 & 489,1 & 26,653 & 0,368 \\
\hline 5 & Sweden & 11417,0 & 47281,0 & 4184,7 & 24,147 & 0,341 \\
\hline$\ldots$ & $\ldots$ & & & & 0,273 \\
\hline 41 & Croatia & 40,2 & 6742,0 & 455,0 & 0,596 \\
\hline
\end{tabular}

Source: Yearbook of CAWAT 2017 [23] (http://www.armstrade.org/files/yearly_2017_1_1.pdf) 
of the USC business activities in the recent years are shown in the tables 3 and 4 .

Table 3 The results of the USC naval shipbuilding for the period from 2014 to 2017

Tablica 3. Rezultati USC vojne brodogradnje za razdoblje 2014. - 2017.

\begin{tabular}{|l|c|c|c|c|}
\hline $\begin{array}{l}\text { Building of ships and vessels, } \\
\text { units }\end{array}$ & 8 & 5 & 8 & 4 \\
\hline Repair of ships and vessels, units & 6 & 7 & 5 & 1 \\
\hline $\begin{array}{l}\text { Service maintenance of ships and } \\
\text { vessels, units }\end{array}$ & 810 & 667 & 798 & 698 \\
\hline
\end{tabular}

Source: Annual report of USC for 2016, 2017 [24]: http://www.oaoosk. ru/upload/iblock/d4f/godovoy-otchet-za-2016-god.pdf, http://www. aoosk.ru/upload/iblock/c3a/god_otchet_2017.pdf

Russia is the biggest exporter of AME in the global market. Lately, there are the following three types of exporting of the naval technique:

- The export of ships out of the current Naval Forces of the exporting country;

The building and transfer of the new ships; and

The transfer of licenses for the shipbuilding.

The major global importers of the naval technique are interested in the creation of their own domestic shipbuilding, so the most promising of these types will eventually be the transfer of licenses for the shipbuilding. The export of ships out of the domestic Naval Forces is gradually diminishing.

The Russian shipbuilders have their strongest positions in the field of building and delivery of the new ships.

For Croatia, the naval shipbuilding is also an essential part of the shipbuilding industry with both its common problems and its positive tendencies of current development. Moreover, even if the start of the reform of the industry in the end of the 20th century had met with considerable difficulties, during the first decade of the 21th century it was exactly the naval rather than the civil sector of Croatian shipbuilding that has first showed signs of the positive development. In all fairness, it must be said that in Croatia the volumes of the naval shipbuilding, mainly directed on the building and overhaul of the so-called minor (or "mosquito") fleet, are ten or even hundred times smaller compared to the civil sector of this industry.

Nevertheless, since 2003 the Croatian company "Adria-MAR Shipbuilding Ltd." plays a dominant role in the naval shipbuilding of the country. The company specializes in the development, building and overhaul of the corvettes, patrol ships, fast-attack missile crafts, amphibious landing vessels, minesweepers, rescue vessels and hospital ships [1]. Beside the Adria-MAR shipbuilding complexes in Split, Trogir and Kraljevica, the naval orders are also fulfilled by the "GREBEN" shipyard, belonging to the national company "MONTMONTAZA-GREBEN Ltd" and situated in the Adriatic Sea on a Croatian island of Korčula. In December 2014, the Croatian Ministry of Defence, following an international tender, concluded a contract with the national company Brodosplit for the supply of five IPV patrol ships for the Coast Guard of the country. The cost of the agreement is estimated at 385.4 million kuna (\$ 63.5 million). The construction of ships is carried out according to a project developed by the Naval Institute (Brodarski institute) located in Zagreb. The construction also involved the company DIV Group. In December 2018, the transfer of the first ship of this series to the Croatian Navy took place [25].

In the beginning of the 21 st century, the companies "Adria-MAR" and "Greben" incorporated the best-practices of their colleagues from the "Viktor Lenac" shipyard in regards of building the ships for the foreign customers. The Croatian shipbuilders have chosen their strategic partners well in advance and established with them a long-term naval and technical co-operation, planning it in such a way that it may be favourable for the development of the national naval shipbuilding and could create the future opportunities for its production to be sold on their partners' markets, including those of the NATO countries [26].

In the creation of the new "mosquito" projects, the Croatian shipbuilders took into the account that some of their foreign customers still consider it necessary to develop the fleet of the quick coastal attack ships (QCAS). In these projects the Croatian shipbuilders implemented the module principle of shipbuilding and the so-cold stealth-technologies (nonshielding, geometrically designed and coloured in a special antiradar way materials for the ship structure), which allowed them to compete with the world's leading exporters of QCAS: CMN, Lurssern, Vosper Thornycroft, "Almaz"(RF) etc. The experience of the shipyards of this Balkan state in the capital overhaul of the surface vessels, and in particular the restitution of the metal structures, allowed some of their foreign customers to undertake the programs of modernization and prolong the life of their naval ships till 2015-2020.

By 2010, more than two thirds of the prototypes of the rescue vessels, naval ships and dual-purpose production, produced by the Croatian shipyards under the "Adria-MAR" and "Greben" companies, became the nation-wide projects. Today USA, Germany, France, Argentina, Austria, Switzerland, UAE, Kuwait, Libya, Saudi Arabia, Spain, Poland, Bulgaria, Italy and Ukraine are regular consumers of these products.

Table 4 Revenue and net profit (in millions of rubles) JSC "USC" and USC-Group in 2012-2017

Tablica 4. Prihodi i neto profit (u milijunima rubalja) JSC "USC" i USC grupe u razdoblju 2012. - 2017.

\begin{tabular}{|l|c|c|c|c|c|c|}
\hline JSC «USC» & 2012 & 2013 & 2014 & 2015 & 2016 & 2017 \\
\hline Revenue & 187,9 & 3975 & 23161 & 22663 & 48612 & 44758 \\
\hline Net profit & $-635,7$ & -391 & 510 & 2080 & 585 & 207 \\
\hline USC-Group & & & & & & \\
\hline Revenue & - & 188620 & 260769 & 280752 & 301946 & 325708 \\
\hline Net profit & - & 3876 & 11409 & 5256 & 3214 & 5914 \\
\hline
\end{tabular}

Source: Annual reports of USC for 2015, 2016, 2017 [24] http://www.oaoosk.ru/upload/iblock/456/godovoy-otchet-ao-osk-2015.pdf, http://www.oaoosk.ru/upload/iblock/d4f/godovoy-otchet-za-2016-god.pdf; htps://www.aoosk.ru/upload/iblock/c3a/god_otchet_2017.pdf 
Table 5 The sales volumes of the countries-exporters of NEA for the period 2008-2015 (mln. US\$ at current prices) Tablica 5. Ukupna prodaja zemalja izvoznica NEA za razdoblje 2008. - 2015. (mil. USD prema sadašnjim cijenama)

\begin{tabular}{|l|l|c|c|c|c|c|}
\hline & & $\begin{array}{c}\text { Combat surface } \\
\text { ships }\end{array}$ & Submarines & $\begin{array}{c}\text { Small craft and minor } \\
\text { landing vessels }\end{array}$ & $\begin{array}{c}\text { Total for all deliveries } \\
\text { of NEA }\end{array}$ & $\begin{array}{c}\text { Country's share in global } \\
\text { sales NEA (\%) }\end{array}$ \\
\hline $\mathbf{1}$ & Russia & 4250,0 & 4270,0 & 1277,0 & 9797,0 & 19,72 \\
\hline 2 & France & 4848,4 & 1424,0 & 1512,7 & 7785,1 & 15,67 \\
\hline 3 & Germany & 1262,7 & 3894,0 & 1296,0 & 6452,7 & 12,99 \\
\hline 4 & Spain & 3890,0 & - & 638,2 & 4528,2 & 9,12 \\
\hline 5 & UK & 2951,2 & - & 871,8 & 3823,0 & 7,70 \\
\hline & $\ldots$ & & & & & 75,5 \\
\hline
\end{tabular}

Source: http://www.armstrade.org/files/analytics/351.pdf (analytical materials of CAMTO for the exhibition EuroNaval-2016)

During the last few decades, the international market of the naval technique, as well as the other weapons and military technique markets, has become an arena of dire competition for the export orders. Many of the developed countries show a lowering of the demand for the new production on the part of their national naval forces, related to the current trend of the optimization of the composition of fleet. The reduced number of domestic orders forces the shipbuilding companies to look for the customers on the global market. At the same time, the limited military budgets of the majority of developing countries further lower the demand for the new technique segment, since these countries prefer to buy the aging vessels or modernize the ones they already have.

In the period 2010-2017, the volume of world supplies of naval technique is estimated at $\$ 67.936$ billion, representing $12.6 \%$ of sales for all categories of AME (fluctuations from $8.3 \%$ in 2011 to $16.3 \%$ - in 2017). According to the estimates of CAWAT, more than 30 countries are currently exporting their naval technique, but the leading positions in this segment of the global AME market belong to the three main players, which are Russia, France and Germany. The best-selling products in the world are the Combat surface ships. According to the results of the 8-year period (20102017), their share constitutes $49 \%$ of the total amount of sales. Small craft and minor landing vessels are in the second place (28.9\%), and the third place goes to submarines (22.1\%) [23]. During this period Russia had the biggest volume of export in all the three categories (19.72\% of the global market in the naval technique segment), France is in the second place (15.67\%), and Germany holds the third (12.99\%) [7]. If we look at the ten topexporting countries for the period from 2008 to 2015, we can also name Spain, UK, Netherlands, USA, Australia, China and Italy in the descending order of the volume of export [27] (see table 5).

For the following four-year period (2016-2019), the CAWAT analysts predict the growing of the naval technique sales (see table 6). 1 The total export volume of NEA for this period they estimate as 47.57 billion dollars (for example, their prognosis for the previous four-year span was more than 1.5 times lower 30.836 billion dollars). In the future period, the combat surface ships will maintain their best-selling position, the second place will go to the non-nuclear submarines, and the small craft will fall down to the third position.

It is necessary to point out that the shipbuilding is such a lengthy process, with the irregular schedule of deliveries, that even the four-year period the CAWAT uses for the estimation of the countries' positions is actually too short. This explains the discrepancies in the market positions and shares of the same countries within the different periods. Yet, it does not change the fact that the main players on the market are the same three countries: France, Germany and Russia.

The main competitors of Russia on the NEA market are as follows: in the Combat surface ships segment they are France, Spain, UK and the Netherlands. In the non-nuclear submarines segment there are only a few exporting countries, such as Germany, France, Sweden, Chile, South Korea and the USA. Yet, the biggest shares of the market belong to the three main players: Germany, Russia and France, which have very nearly divided the total volume of sales among them (see table 7). Finally, the small craft and minor landing vessels segment includes the most wide group of the exporting countries, among them shipbuilders from the Western Europe, e. g. from

Table 6 The CAWAT prognosis of the sales volumes of the countries-exporters of NEA for the period from 2016 to 2019 (mln. US\$ at current prices) Tablica 6. CAWAT prognoza ukupne prodaje zemalja izvoznica NEA za razdoblje 2016. - 2019. (mil. USD prema sadašnjim cijenama)

\begin{tabular}{|l|l|c|c|c|c|c|}
\hline & & $\begin{array}{c}\text { Combat surface } \\
\text { ships }\end{array}$ & Submarines & $\begin{array}{c}\text { Small craft and minor } \\
\text { landing vessels }\end{array}$ & $\begin{array}{c}\text { Total for all deliveries } \\
\text { of NEA }\end{array}$ & $\begin{array}{c}\text { Country's share in global } \\
\text { sales NEA (\%) }\end{array}$ \\
\hline $\mathbf{1}$ & Germany & 2721,9 & 5658,5 & 997,3 & 9377,7 & 20,58 \\
\hline 2 & France & 5072,3 & 3430,9 & 548,0 & 9051,2 & 19,03 \\
\hline 3 & Russia & 3260,0 & 2394,0 & 1017,5 & 6671,5 & 14,02 \\
\hline 4 & Australia & 2425,9 & - & 1262,2 & 3688,1 & 7,75 \\
\hline 5 & Spain & 3466,7 & - & 181,0 & 3647,7 & 7,67 \\
\hline & $\ldots$ & & & & 7,5 & 0,016 \\
\hline
\end{tabular}

Source: http://www.armstrade.org/files/analytics/351.pdf (analytical materials of CAMTO for the exhibition EuroNaval-2016) 
Table 7 Leaders by the volume of deliveries in terms of individual types of NEA within the period 2009-2016.

Tablica 7. Najveći isporučitelji individualnih tipova NEA u razdoblju 2009. - 2016.

\begin{tabular}{|l|c|c|c|}
\hline \multicolumn{1}{|c|}{ Categories of NEA } & $1^{\text {st }}$ place & $2^{\text {nd }}$ place & $3^{\text {rd }}$ place \\
\hline Combat surface ships & France $(18,5 \%)$ & Russia (15,3\%) & Spain (12,3\%) \\
\hline Non-nuclear submarines & Germany $(49,3 \%)$ & Russia (38,6\%) & France (10,0\%) \\
\hline Small craft and minor landing vessels & Netherlands (13,0\%) & Russia (10,8\%) & France (10,6\%) \\
\hline
\end{tabular}

Source: Yearbook of CAWAT 2017 (http://www.armstrade.org/files/yearly_2017_1_1.pdf)

Croatia, but also from Australia, USA, Turkey, China and other countries. If estimated for the eight-year period from 2009 to 2016 according to the actual monetary volume of the deliveries of the naval technique of major types, Russia held the second place in all the above-listed types of NEA.

According to the latest prediction of the CAWAT in 20172020 the situation may somewhat change (table 8).

Despite the fact that according to this prediction Russia will fall to the third place in the total rating of the exporters, it will retain its market share in regards of the combat surface ships, but step a bit down in regards of the conventional submarines. The small craft and minor landing vessels segment houses a large number of exporting countries, thus the situation with the market shares there is shifting very quickly. In any case, though, Russia was, is and will continue to be one of the major players on the global naval technique market.

The group of countries-importers of NEA is much more crowded than the group of the exporters. The biggest importers on the naval shipbuilding market are India, Vietnam, UAE, Australia, USA, Egypt and etc. According to the actual monetary volume of purchases within the eight-year period (2009-2016), the chief buyers of the specific types of naval technique line up as follows (see table 9):

The CAWAT prognosis for the future volumes of import by the major buyers of naval technique for the period of 2017-2020 is shown in the table 10.
The Saudi Arabia is lately gradually taking up the position of the main importer of all kinds of weapons and military technique, including the naval one, which it orders predominantly from the USA. The share of the USA in the total import of Saudi Arabia is already around $50 \%$ and constantly growing. The naval technique though, the Saudis buy mainly in France (frigates). Russia practically does not sell its products to Saudi Arabia. The traditional buyers of Russian naval technique are India, Vietnam, Egypt and Algeria.

India is the second biggest importer of NEA in the world. The Russian share in the total import NEA of India has until recently constituted around $50 \%$, but the prognosis predicts that it will diminish (down to approx. 34\% in 2017-2020). From RF India has bought the frigates and the aircraft carrier, while the submarines it has imported from France.

Within the import structure of the third biggest importer, namely, the UAE, Russia takes up a minor part of about $4 \%$ only, though the prognosis for 2017-2020 predicts an increase [23]. The UAE is currently buying the naval technique from France (corvettes) and Germany (corvettes and support ships)

Vietnam imports from Russia the patrol craft, as well as the frigates. Another major importer of the naval technique - Egypt - buys patrol craft from Russia and the USA, and the frigates and major landing craft ("Mistral") - from France. Algeria imports from Russia the small craft and the submarines [22].

Table 8 Predicted leaders by the volume of deliveries in terms of individual types of NEA within the period 2017-2020. Tablica 8. Predviđeni najveći isporučitelji individualnih tipova NEA u razdoblju 2017. - 2020.

\begin{tabular}{|l|c|c|c|}
\hline \multicolumn{1}{|c|}{ Categories of NEA } & $1^{\text {st }}$ place & $2^{\text {nd }}$ place & $3^{\text {rd }}$ place \\
\hline Combat surface ships & Spain $(22,4 \%)$ & France $(19,3 \%)$ & Russia $(15,3 \%)$ \\
\hline Non-nuclear submarines & France $(35,3 \%)$ & Germany $(29,2 \%)$ & Russia $(26,1 \%)$ \\
\hline Small craft and minor landing vessels & unknown $(22,5 \%)$ & Netherlands $(17,3 \%)$ & Germany $(11,6 \%)$ \\
\hline
\end{tabular}

Source: Yearbook of CAWAT 2017 (http://www.armstrade.org/files/yearly_2017_1_1.pdf)

Table 9 The major importers of the specific types of NEA in the monetary volumes for the period of 2009-2016.

Tablica 9. Najveći uvoznici specifičnih tipova NEA prema količini utrošenoga novca za razdoblje 2009. - 2016.

\begin{tabular}{|l|c|c|c|}
\hline \multicolumn{1}{|c|}{ Categories of NEA } & $1^{\text {st }}$ place & $2^{\text {nd }}$ place & $3^{\text {rd }}$ place \\
\hline Combat surface ships & India $(14,9 \%)$ & Egypt $(12,1 \%)$ & USA (9,0\%) \\
\hline Non-nuclear submarines & Vietnam $(21,4 \%)$ & Greece $(16,4 \%)$ & Israel $(10,9 \%)$ \\
\hline Small craft and minor landing vessels & USA $(12,8 \%)$ & UAE (5,5\%) & Vietnam (5,2\%) \\
\hline
\end{tabular}

Source: Yearbook of CAWAT 2017 (http://www.armstrade.org/files/yearly_2017_1_1.pdf)

Table 10 Predicted leaders in the import of the specific types of NEA in the monetary volumes for the period of 2017-2020. Tablica 10. Predviđeni vodeći uvoznici specifičnih tipova NEA prema količini utrošenoga novca za razdoblje 2017. - 2020.

\begin{tabular}{|l|c|c|c|}
\hline Categories of NEA & $1^{\text {st }}$ place & $2^{\text {nd }}$ place & $3^{\text {rd }}$ place \\
\hline Combat surface ships & Australia $(23,3 \%)$ & USA $(12,7 \%)$ & Algeria $(12,6 \%)$ \\
\hline Non-nuclear submarines & India $(41,2 \%)$ & Algeria $(8,7 \%)$ & Egypt $(8,4 \%)$ \\
\hline Small craft and minor landing vessels & Saudi Arabia $(23,9 \%)$ & USA $(11,3 \%)$ & Qatar $(10,4 \%)$ \\
\hline
\end{tabular}

Source: Yearbook of CAWAT 2017 (http://www.armstrade.org/files/yearly_2017_1_1.pdf) 


\section{CONCLUSIONS / Zaključci}

The results of the analysis led the authors to the following conclusions and allowed them to provide some recommendations:

1. The systemic crisis that affected the major part of the global economy starting with 1990s did not spare the shipbuilding industry. The shipbuilding countries had to carry out some painful and quite costly (considering the specifics of the industry) reforms, aimed both on the heightening of the efficiency of the industry, and - often simply on its survival in the situation of the escalating competition on the global market.

2. The successful previous co-operation of the Croatian and Russian shipbuilders should be further developed, widened and deepened. The almost "mirror-like" structure of the shipbuilding industries of our two countries (the predominance of the civil segment in Croatia and the naval one - in Russia) does in no way preclude and even in fact promotes their successful co-operation in this field. In the global market, we are not competitors, but could become mutually profitable partners.

3. The successful development of the national shipbuilding does not only depend on the existence of an extensive domestic demand. Without a doubt, the great amount of the minimum effective scale (MES) demands that our national shipbuilders should have a considerable new-building program based on the external customers' orders. Despite the fact that the predominant share of Croatian shipbuilding is private and may even belong to the foreign capital, among the problems still actual for this industry (for Croatia and Russia as well), there is the need for the state support, considering the lengthy production cycle, big capital investments, lengthy pay-off period, and irregular profits. The industry also needs some long-term, big and guaranteed credit lines and the insurance of its high risks.

4. Croatia and Russia hold traditionally high positions in the global and European ratings of the biggest shipbuilding countries (Croatia is among the three biggest exporters in Europe and in the top-10 on the global market, Russia is among the three major global exporters of the naval technique). Yet, to maintain the leading positions on the global market, one needs to be flexible in the reaction towards the changes in the global environment, timely foresee the shifts of interests of the importing countries, and try to preserve the traditional market channels and to enter and solidify one's position in the new markets.

5. The state and perspective development of the Russian shipbuilding industry has long held the interest for the authors of this article. However, the analysis of problems and best practices of the development of the shipbuilding in the other countries (in this case - Croatia) is a new and undoubtedly interesting and useful experience for us. By exchanging our experience of solving the similar problems with the Croatian researchers, we should be able to come up with some common conclusions and recommendations

\section{REFERENCES / Literatura}

[1] Irinin, M. (2010). "Shipbuilding and naval shipbuilding in Croatia". FLOT. com. https://flot.com/nowadays/concept/opposite/shipbuildingincroatia. htm? print=Y [accessed 11/8/2018]

[2] Tulyakova, I. R., Gregova, E., Dengov, V. V. (2017). "Assessment of Competitiveness of Shipbuilding Industry in Russia". Naše more, Vol. 64, No. 3, pp. 112-119. https://doi.org/10.17818/nm/2017/3.6

[3] Gecont.ru (2014). "Economy of Croatia: industry, energy, transport, trade". http://www.gecont.ru/articles/econ/croatia.htm [accessed 11/8/2018]

[4] Virglerova, Z., Homolka, L., Smrcka, L., Lazanyi, K., Kliestik, T. (2017). “Key Determinants of the Quality of Business Environment of SMEs in the Czech Republic". E \& M: Ekonomie a Management, Vol. 20, No. 2, pp. 87-101. https:// doi.org/10.15240/tul/001/2017-2-007

[5] Gasparac, B., Grubisic, R. (2008). "Analysis of the World's Shipbuilding Market with a Reference to the State of the Croatian Shipbuilding Industry". Brodogradnja, Vol. 59, No. 3, pp. 262-271.

[6] Barisic, Z. (2008). “What's New in Croatian Shipbuilding?". Brodogradnja, Vol. 59 No. 1, pp. 69-70.

[7] Logatchev, S. I., Chugunov, V. V. (2013). "Impact of financial crisis on the development of world shipbuilding". http://www.maritimemarket.ru/article. phtml?id=1073 [accessed 11/8/2018]

[8] Maritime-zone.com (2013). "Trends in world shipbuilding 2013". http://maritime-zone.com/articles/trends-of-world-shipbuilding [accessed 15/6/2013]

[9] Sudostroenie.info (2018). "The world shipbuilding market in 2017: volume and structure of orders". http://sudostroenie.info/analitika/91.html [accessed $11 / 8 / 2018]$

[10] Sudostroenie.info (2016). "Shipbuilding in Croatia: second in Europe and the tenth in the world". http://sudostroenie.info/analitika/37.html [accessed $11 / 8 / 2018]$

[11] Dw.com/ru (2018). "The global crisis in shipbuilding bypassed Europe". http:// www.dw.com/ru/\%D0\%BC\%D0\%B8\%D1\%80\%D0\%BE\%D0\%B2\%D0\%BE\%D 0\%B9-\%D0\%BA\%D1\%80\%D0\%B8\%D0\%B7\%D0\%B8\%D1\%81-\%D0\%B2-\%D1 \%81\%D1\%83\%D0\%B4\%D0\%BE\%D1\%81\%D1\%82\%D1\%80\%D0\%BE\%D0 \%B5\%D0\%BD\%D0\%B8\%D0\%B8-\%D0\%BE\%D0\%B1\%D0\%BE\%D1\%88\%D0\% B5\%D0\%BB-\%D1\%81\%D1\%82\%D0\%BE\%D1\%80\%D0\%BE\%D0\%BD\%D0\%BE \%D0\%B9-\%D0\%B5\%D0\%B2\%D1\%80\%D0\%BE\%D0\%BF\%D1\%83/a-41535409 [accessed 11/8/2018]. https://doi.org/10.33941/age-info.com24(5)2018005

[12] Kliestikova, J., Misankova, M., Kliestik, T. (2017). "Bankruptcy in Slovakia: international comparison of the creditor's position". Oeconomia Copernicana, Vol. 8, No. 2, pp. 221-237. https://doi.org/10.24136/oc.v8i2.14

[13] Kliestik, T., Misankova, M., Valaskova, K. (2018). "Bankruptcy Prevention: New Effort to Reflect on Legal and Social Changes". Science and Engineering Ethics, Vol. 24, No. 2, pp. 791-803. https://doi.org/10.1007/s11948-017-9912-4

[14] Rabar, D. (2015). "Setting key performance targets for Croatian shipyards" Croatian Operational Research Review, Vol. 6, No. 1, pp. 279-291. https://doi. org/10.17535/crorr.2015.0022

[15] Sladoljev, Z. (2008). "Croatian shipbuilding industry - challenges and opportunities". Brodogradnja, Vol. 59, No. 2, pp. 163-165.

[16] Hadzic, N., Tomic, M., Vladimir, N., Ostojic, S., Senjanovic, I. (2015). "Current State and Perspectives of the Croatian Shipbuilding Industry". Journal of Naval Architecture and Marine Engineering, Vol. 12, No. 1, pp. 33-42.

[17] Pribičević, V. (2018). "The Hard Battle for Croatian Shipbuilding Has Not Been Lost Yet". Euractiv.jutarnji.eu. https://euractiv.jutarnji.hr/en/croatiaand-the-eu/the-hard-battle-for-croatian-shipbuilding-has-not-been-lostyet/7786029/ [accessed 3/9/2018]

[18] Logatchev, S. I. (2013). "Where there is always something to surprise and evolve”. http://www.korabel.ru/news/comments/logachev_stanislav_ivanovich_ vsegda_est_kuda_razvivatsya_i_chem_udivit.html [accessed 11/8/2018]

[19] Valaskova, K., Kliestik, T., Svabova, L. Adamko, P. (2018). "Financial Risk Measurement and Prediction Modelling for Sustainable Development of Business Entities Using Regression Analysis". Sustainability, Vol. 10, No. 7, p. 2144. https://doi.org/10.3390/su10072144

[20] Dengov, V. V., Tulyakova, I. R. (2015). "Credit Risk Analysis for the Telecommunication Companies of Russia: Fuzzy Model. Comparison of the Results". SGEM 2015: Political Sciences, Law, Finance, Economics and Tourism, Vol II: Finance, Economics \& Tourism. Book Series: International Multidisciplinary Scientific Conferences on Social Sciences and Arts, pp. 123-130. https://doi. org/10.5593/sgemsocial2015/b22/s6.016

[21] Dengov, V. V., Gregova, E. (2015). "Global Experience in Overcoming Adverse Selection in the Insurance Markets". Proceedings of the 15th International Scientific Conference on Globalization and its Socio-Economic Consequences, Part I. Zilina, Slovakia, pp. 102-109.

[22] SIPRI (2018). http://armstrade.sipri.org/armstrade/html/export_values. php; https://www.sipri.org/databases/ armsindustry; http://armstrade.sipri. org/armstrade/page/trade_register.php [accessed 11/8/2018]. https://doi. org/10.1017/s0084255900049767

[23] CAWAT $(2017,2018)$. Yearbook of CAWAT 2017, 2018. http://www.armstrade org/files/yearly_2017_1_1.pdf [accessed 11/8/ 2018]; http://www.armstrade. org/files/yearly_2018_3_1.pdf. [accessed 23/5/ 2019]

[24] Annual reports of USC for 2015, 2016, 2017. http://www.oaoosk.ru/upload/ iblock/456/godovoy-otchet-ao-osk-2015.pdf; http://www.oaoosk.ru/upload/ iblock/d4f/godovoy-otchet-za-2016-god.pdf; http://www.aoosk.ru/upload/ iblock/c3a/god_otchet_2017.pdf. https://doi.org/10.15363/thinklab.d138

[25] VPK.NAME (2018). "Croatian Navy received the first patrol ship of national construction". https://vpk.name/news/238064_vms_horvatii_poluchili_ pervyii_patrulnyii_korabl_nacionalnoi_postroiki.html [accessed 14/12/2018]

[26] Kasum, J., Pavic I., Miskovic, J. (2013). "Increase of Combat Effectiveness of Warships with the Introduction into Operation of WECDIS". Naše more, Vol. 60, No. 3-4, pp. 55-60

[27] CAWAT (2012). "World exports of naval equipment in 2005-2012 and forecasts for the period 2013-2016". http://www.armstrade.org/includes/ periodics/expo/2012/1021/111715299/detail.shtml [accessed 11/8/2018] 